\section{DOA Jopectory of \\ OPEN ACCESS \\ JOURNALS}

P-ISSN: 2548-5962

E-ISSN: $2548-981 \mathrm{X}$

https://ojs.unud.ac.id/index.php/jbn

\section{CASE REPORT}

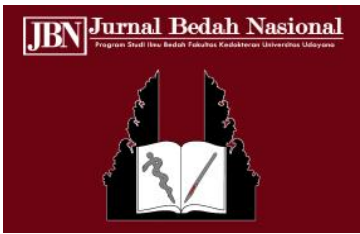

\title{
Diagnosis dan Tatalaksana Ruptur Diafragma pada Fase Akut dan Fase Laten
}

\section{Rizky Amaliah*}

Fakultas Kedokteran Universitas Indonesia - Rumah Sakit Umum Pusat Nasional Cipto Mangunkusumo

*Penulis korespondensi: r_amaliah@yahoo.com.

\begin{abstract}
ABSTRAK
Latar belakang: Diafragma akan ruptur apabila terjadi trauma akselerasi-deselerasi dengan energi yang tinggi akibat dari peningkatan tekanan intraabdomen yang tiba-tiba meninggi. Diagnosis dan tatalaksana akan berbeda pada kasus ruptur diafragma yang terjadi pada fase akut dan fase laten. Kasus: Kami melaporkan dua kasus ruptur diafragma fase akut dan fase laten dengan dua pendekatan operasi yang berbeda. Kasus pertama adalah laki-laki, 59 tahun, dirujuk dengan riwayat kecelakaan lalu lintas 38 jam sebelum masuk rumah sakit. Pasien datang dengan gejala dispnoe dan foto polos toraks yang memperlihatkan adanya herniasi gaster ke rongga toraks kiri melalui defek pada diafragma. Pasien dilakukan CT scan torakoabdominal dan disimpulkan adanya ruptur diafragma kiri pada bagian posterior dengan herniasi gaster dan mesenterium. Pasien dilakukan laparotomi untuk memperbaiki diafragma dengan interrupted suture menggunakan benang nonabsorbable. Kasus kedua adalah wanita, 46 tahun, datang dengan keluhan dispepsia, mual dan muntah. Nyeri tidak hilang dengan tatalaksana dispepsia. Hasil foto polos toraks memperlihatkan elevasi hemidiafragma kiri. Dengan diagnosis eventratio, pasien direncanakan torakotomi posterolateral kiri. Intraoperatif, ditemukan ruptur diafragma kiri dengan herniasi dan perforasi gaster. Setelah ditelusuri pasien mempunyai riwayat kecelakaan lalu lintas 6 bulan sebelumnya. Pasien dilakukan pula laparotomi untuk melakukan adhesiolisis gaster dan paru yang telah melekat dan memperbaiki diafragma dengan interrupted suture menggunakan benang nonabsorbable serta melakukan jahit primer pada perforasi gaster. Simpulan: Tindakan operasi merupakan tindakan yang wajib dilakukan untuk memperbaiki diafragma. Pendekatan yang dipakai baik laparotomi atau torakotomi tergantung dari kelainan organ lainnya, akut atau laten suatu kasus, stabil atau tidak stabil kondisi pasien serta pengalaman operator.
\end{abstract}

Kata kunci: ruptur diafragma, laparotomi, torakotomi.

DOI: https://doi.org/10.24843/JBN.2020.v04.i01.p05

\begin{abstract}
Background: A diaphragm will rupture if there is a high-energy acceleration-deceleration trauma due to a sudden increase in intraabdominal pressure. Diagnosis and management will be different in cases of diaphragmatic rupture that occur in the acute phase and latent phase. Case: We report two cases of acute and latent phase diaphragmatic ruptures with different surgical approaches. The first case is a male, 59 years old, with a history of traffic accidents 38 hours before hospital admission. Patients felt dyspnoea. Plain chest X-ray showed gastric herniation into the left thoracic cavity. Left diaphragmatic rupture in the posterior section with gastric and mesenteric herniation was seen in CT scan. The patient underwent laparotomy to repair the diaphragm. The second case is a woman, 46 years old, who presented with dyspepsia, nausea and vomiting that did not disappear with the treatment of dyspepsia. Plain chest radiograph showed eventration of the left hemidaphragm. The patient underwent left posterolateral thoracotomy. Intraoperatively, a left diaphragmatic rupture was found with herniation and gastric perforation. After trace back to the patient, she has a history of traffic accidents 6 months before. Laparotomy was performed and adhesiolysis between stomach and lung was done. Repair the diaphragm and the stomach were performed. Conclusion: Surgery is an action that must be done to repair the diaphragm. Choosing the surgical approaches either by laparotomy or thoracotomy depends
\end{abstract}


on the abnormalities of other organs, acute or latent of a case, stable or unstable condition of the patient and the experience of the operator.

Keywords: diaphragm rupture, laparotomy, thoracotomy.

\section{PENDAHULUAN}

Diafragma merupakan organ aponeurotik berotot yang memisahkan rongga toraks dan abdomen. Diafragma berkembang dari membran pleuroperitoneal dan dinding tubuh, mesenterium bagian dorsal dari esofagus dan septum transversum semenjak embrio. Diafragma akan terjadi ruptur apabila terjadi trauma akselerasi-deselerasi dengan energi yang tinggi akibat dari peningkatan tekanan intraabdomen yang tiba-tiba meninggi. Kecurigaan tinggi akan adanya ruptur diafragma harus ada di benak dokter jika terdapat riwayat trauma dengan intrusi kompartemen abdomen $\geq 30 \mathrm{~cm}$ (terutama bagian lateral), perubahan kecepatan $\geq 40$ $\mathrm{km} / \mathrm{jam}$, berkaitan dengan trauma pada hati atau limpa, tulang iga atau fraktur pelvis serta ruptur aorta torakalis. Kasus ruptur diafragma merupakan suatu kondisi yang jarang terjadi yang biasanya terjadi akibat kecelakaan lalu lintas (KLL) yaitu sebesar $80 \%$ dari seluruh ruptur diafragma. ${ }^{1}$ Insiden terjadinya ruptur diafragma sebesar $0,8-5,8 \%$ pada trauma tumpul dan $2,5-5 \%$ pada trauma tumpul abdomen dan $1,5 \%$ pada trauma tumpul toraks. ${ }^{2}$ Sedangkan pada pasien trauma tusuk, kejadian ruptur diafragma sebesar $15 \% .^{3}$ Ruptur diafragma yang didapatkan intraoperatif saat laparotomi dan torakotomi sebesar 4-6\%. ${ }^{1}$ Sehingga angka kejadian ruptur diafragma sebenarnya lebih besar dari data yang ada sebelumnya. Diagnosis ruptur diafragma pada saat akut sulit ditegakkan dan biasanya terlambat. Ruptur yang tidak terdeteksi dilaporkan sebanyak 50\% kasus. Shah dkk. memperlihatkan pasien yang terdiagnosis ruptur diafragma preoperatif sebesar 43,5\%, diagnosis saat dilakukan otopsi dan eksplorasi intraoperatif sebesar $41,3 \%$, dan sisanya diagnosis ditegakkan terlambat. Keterlambatan diagnosis akan meningkatkan morbiditas dan mortalitas pasien.

Tatalaksana terbaik untuk pasien yang terjadi ruptur diafragma adalah melakukan tindakan operasi. Belum ada satupun kasus ruptur diafragma yang sembuh spontan. Hal ini terjadi karena adanya perbedaan tekanan antara rongga abdomen dan rongga toraks sehingga menyebabkan sedikit saja adanya ruptur pada diafragma maka akan terjadi herniasi organ-organ abdomen masuk ke rongga toraks. Tindakan operasi dapat dilakukan baik melalui toraks (torakotomi) maupun abdomen (laparotomi). Sampai saat ini belum ada penelitian yang menjelaskan tindakan operasi terbaik yang dapat dilakukan untuk pasien dengan ruptur diafragma.

\section{LAPORAN KASUS}

\section{Kasus 1}

Laki-laki berusia 59 tahun dirujuk dengan suspek ruptur diafragma sinistra ke rumah sakit dengan riwayat kecelakaan lalu lintas 38 jam sebelum masuk rumah sakit yang menyebabkan trauma pada dada dan abdomen. Saat pasien datang, pasien dalam keadaan sadar penuh dengan keluhan sesak nafas dengan frekuensi nafas 30 kali per menit dan tensi darah sebesar 190/100 mmHg. Pada pemeriksaan fisik didapat dada kiri tertinggal saat bernafas, hipersonor pada perkusi, dan tidak ditemukan tanda peritonitis. Dari hasil foto polos toraks AP/lateral dan ultrasonografi abdomen dapat disimpulkan terdapat herniasi gaster akibat ruptur diafragma akibat trauma tumpul karena kecelakaan lalu lintas. Foto 
polos abdomen memperlihatkan tidak adanya udara atau cairan bebas pada rongga peritonium sehingga disimpulkan organ abdomen intak. Hasil CT scan pada Gambar 1 dan Gambar 2 dapat disimpulkan terdapat ruptur diafragma posterior kiri berdiameter 8 $\mathrm{cm}$ yang menyebabkan herniasi gaster dan lemak mesenterium ke rongga toraks kiri disertai kolaps paru kiri. Tidak ditemukan kelainan lain pada organ-organ lain intra abdomen dan toraks.

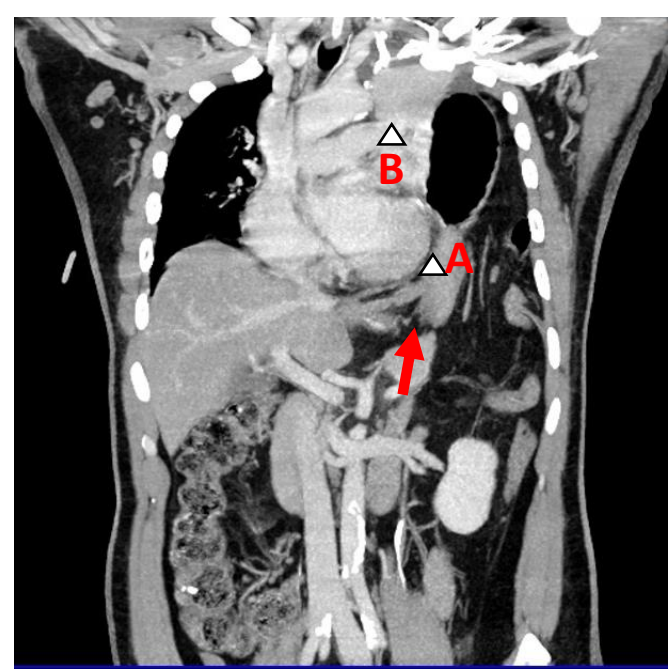

Gambar 1. Gambaran CT scan torakoabdominal pada kasus 1 sebelum dilakukan operasi pada potongan koronal. Gambaran ini memperlihatkan adanya diskontinuitas diafragma (panah). Herniasi gaster dan lemak mesenterium ke rongga toraks kiri (mata panah A) yang menekan bronkus utama kiri menyebabkan kolaps paru kiri (mata panah B). Herniasi melewati defek pada bagian posterior diafragma kiri berdiameter $8 \mathrm{~cm}$.

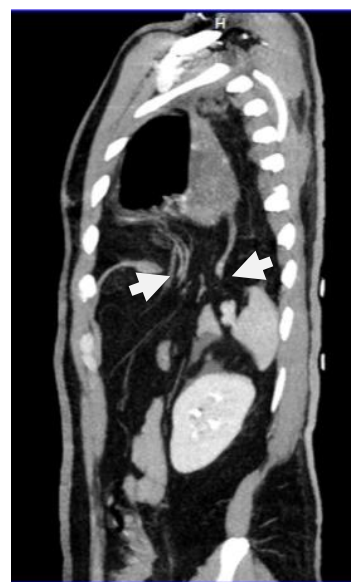

Gambar 2. Gambaran CT scan torakoabdominal pada kasus 1 sebelum dilakukan operasi pada potongan sagital. Gambar memperlihatkan adanya collar sign (panah).
Pasien dilakukan laparotomi eksplorasi untuk memperbaiki ruptur diafragma. Intraoperatif dilakukan pengembalian gaster ke dalam rongga abdomen dan diafragma dijahit dengan interrupted suture menggunakan benang nonabsorbable pada bagian ruptur yaitu pada doom diafragma sebelah kiri di bagian posterior. Tidak ditemukan iskemia dan perforasi pada gaster. Tampak seluruh organ intra abdomen dan bagian paru sebelah kiri intak. Operasi dilakukan selama 2 jam 45 menit. Pasien dipasang chest tube dengan Water Sealed Drainage (WSD) intrapleura kiri serta drain intraabdomen pada bagian subdiafragma kiri. Gambar 3 memperlihatkan foto polos toraks paska operasi. Drain pada subdiafragma dilepas pada hari ketiga paska operasi. Chest tube dilepas pada hari keempat paska operasi. Pasien dirawat inap selama 7 hari dan tidak ditemukan komplikasi paska operasi.

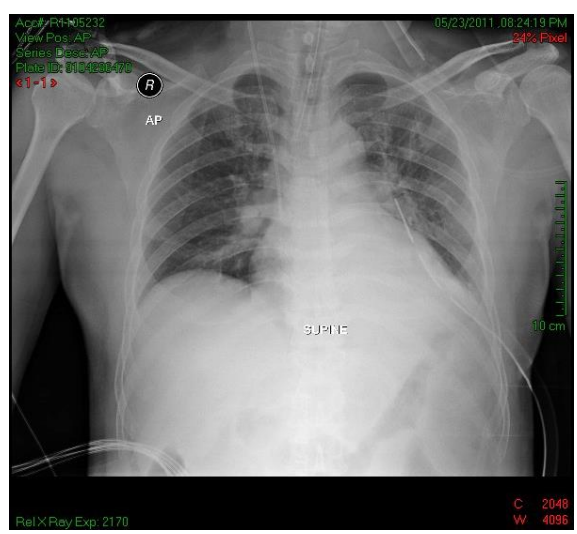

Gambar 3. Gambaran foto polos toraks pada kasus 1 setelah operasi. Tampak diafragma telah diperbaiki dan tidak terdapat herniasi visera abdominal di rongga toraks. Paru kiri telah mengembang sempurna.

\section{Kasus 2}

Wanita, 46 tahun, datang dengan keluhan nyeri pada perut bagian atas yang terus menerus, mual dan muntah. Pasien tidak merasakan sesak. Pemeriksaan fisik memperlihatkan tidak ditemukan tanda-tanda akut abdomen. Pasien dirawat inap dengan 
rencana tatalaksana ulkus gaster namun tidak terdapat perbaikan. Hasil foto polos toraks memperlihatkan elevasi diafragma kiri seperti terlihat pada Gambar 4.

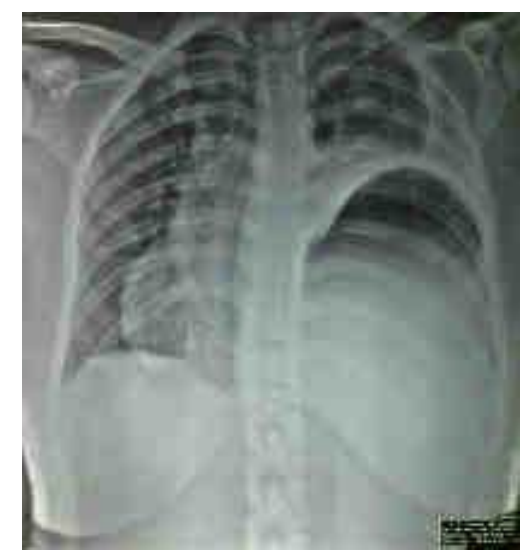

Gambar 4. Gambaran foto polos toraks pada kasus 2 sebelum dilakukan operasi. Tampak diafragma kiri terangkat dan menekan paru kiri.

Dengan dugaan eventratio, tanpa dilakukan CT scan terlebih dahulu, pasien dilakukan torakotomi melalui insisi posterolateral sinistra. Intraoperatif ditemukan bahwa diafragma tidak intak, terdapat ruptur pada diafragma bagian posterolateral sepanjang 6 $\mathrm{cm}$, ditemukan pula hernia gaster. Pada saat melepaskan adhesi organ tersebut dari intratorakal, ditemukan perforasi pada gaster yang kemudian mengotori peritonium sehingga diputuskan untuk dilakukan laparotomi. Operasi dilanjutkan untuk memperbaiki ruptur diafragma dan perforasi gaster. Keduanya dijahit primer dengan interrupted suture. Ruptur diafragma sangat rapuh sehingga sukar dijahit dan diperlukan insisi terlebih dahulu. Setelah ditelusuri, pasien mempunyai riwayat kecelakaan lalu lintas pada 6 bulan sebelumnya. Paska operasi, pasien dipasang chest tube dengan Water Sealded Drainage (WSD) dan drain pada bagian subdiafragma kiri. Pasien dirawat di ICU, selama perawatan beberapa hari, terdapat ruptur kembali pada diafragma sehingga diperlukan relaparotomi. Setelah laparotomi kedua, keadaan pasien membaik dan tidak ditemukan komplikasi lainnya.

\section{DISKUSI}

Pada sebuah literatur dijelaskan bahwa ruptur diafragma dapat terjadi 4 kali lebih sering pada laki-laki dengan dekade usia ke3. ${ }^{4}$ Trauma tumpul menjadi penyebab tersering yaitu sebesar $80 \%$ kasus, diikuti dengan jatuh dari ketinggian (10\%) dan trauma tajam (10\%). Ruptur diafragma bagian kiri sebesar $68,5-73,9 \%, 24,2-26,1 \%$ terjadi pada bagian kanan, $1,5 \%$ terjadi bilateral, $0,9 \%$ perikardial, dan $5 \%$ tidak terklasifikasi. ${ }^{5,6}$ Kebanyakan ruptur diafragma mempunyai defek lebih panjang dari $10 \mathrm{~cm}$ dan terjadi pada aspek posterolateral. Hal ini terjadi karena lokasi tersebut secara struktural lemah karena merupakan membran pleuroperitoneal. Ruptur diafragma pada sebelah kiri lebih sering terjadi daripada kanan karena efek protektif dari hati, underdiagnosis pada ruptur hemidiafragma kanan serta lemahnya lokasi hemidiafragma kiri akibat fusi embrionik. ${ }^{6}$

Diagnosis ruptur diafragma sulit ditegakkan pada pasien multipel trauma karena tampilan pasien saat datang lebih memperlihatkan kelainan lainnya. Grimes mendeskripsikan tiga fase presentasi gejala dan tanda yang terdapat pada ruptur diafragma, yaitu fase akut, fase laten dan fase obstrutif. Tabel 1 memperlihatkan fase-fase ruptur diafragma menurut Grimes. ${ }^{7}$

Reber melaporkan waktu antara trauma sampai ditegakkannya ruptur diafragma berkisar 20 hari sampai 50 tahun. ${ }^{3}$ Diagnosis pada kasus 1 ditemukan saat fase akut, namun karena keterbatasan sumber daya pada rumah sakit pertama, maka pasien dirujuk sehingga mengalami keterlambatan dalam operasi. CT scan dilakukan untuk mengeksklusi kelainan lainnya pada organ toraks dan abdomen sehingga berguna untuk memilih pendekatan 
yang dilakukan pada pasien. Dengan klinis dipastikan adanya ruptur diafragma tanpa ada pasien serta 3 modalitas pencitraan yaitu foto kelainan organ abdomen maupun toraks toraks, USG abdomen, dan foto polos sehingga tidak diperlukan pemeriksaan CT abdomen 3 posisi sebenarnya sudah dapat scan.

Tabel 1. Gejala dan Tanda pada Ruptur Diafragma Menurut Grimes ${ }^{7}$

\begin{tabular}{|c|c|c|}
\hline Fase Akut & Fase Laten & Fase Obstruktif \\
\hline $\begin{array}{l}\text { Terjadi sejak kejadian trauma } \\
\text { sampai terdapat gejala yang nyata } \\
\text { terjadinya trauma. } \\
\text { - Nyeri abdomen } \\
\text { - Kelainan lainnya akibat } \\
\text { trauma (dinding abdomen dan } \\
\text { toraks, pelvis, kepala, } \\
\text { ekstremitas, } \\
\text { hemopneumotoraks, organ } \\
\text { visera abdomen) } \\
\text { - Instabilitas hemodinamik } \\
\text { - Distres pernapasan } \\
\text { - Berkurangnya udara yang } \\
\text { masuk pada sisi yang terkena } \\
\text { Terdengarnya suara bising } \\
\text { usus pada auskultasi dada } \\
\text { (patognomonik) } \\
\text { Kelainan pada foto polos } \\
\text { toraks } \\
\text { Defek teridentifikasi saat } \\
\text { operasi emergensi } \\
\text { (laparotomi) }\end{array}$ & $\begin{array}{l}\text { Fase ini terjadi saat organ } \\
\text { intraabdomen melewati defek dan } \\
\text { memasuki rongga toraks dan dapat } \\
\text { terjadi beberapa jam sampai } \\
\text { minggu setelah trauma. Hal ini } \\
\text { mengurangi kapasitas fungsional } \\
\text { pada toraks. } \\
\text { - Nyeri pada abdomen bagian } \\
\text { atas } \\
\text { - Dipsnoe dan sianosis } \\
\text { - Takikardi } \\
\text { - Nyeri substernal atau nyeri } \\
\text { alih ke bahu } \\
\text { - Gelisah } \\
\text { - Dipsnoe yang dieksaserbasi } \\
\text { oleh posisi berbaring } \\
\text { Perkusi redup } \\
\text { berkurangnya suara nafas } \\
\text { pada sisi yang terkena } \\
\text { Terdengarnya suara bising } \\
\text { usus pada auskultasi dada } \\
\text { Kelainan pada foto polos } \\
\text { toraks }\end{array}$ & $\begin{array}{l}\text { Terjadi beberapa bulan sampai } \\
\text { tahun setelah trauma ketika visera } \\
\text { yang mengalami hernia terjadi } \\
\text { obstruksi dan strangulata. Delapan } \\
\text { pulu lima persen kejadian } \\
\text { strangulata terjadi ada } 3 \text { tahun } \\
\text { pertama setelah trauma. } \\
\text { - Mual dan muntah } \\
\text { - Gejala obstruksi usus atau } \\
\text { iskemia dan perdarahan } \\
\text { - Gangguan pernafasan kronik } \\
\text { akibat atelektasis dan } \\
\text { pneumonitis } \\
\text { Pergeseran mediastinum } \\
\text { - Trias Borchardts yaitu nyeri } \\
\text { abdomen bagian atas dan } \\
\text { distensi, muntah-muntah serta } \\
\text { tidak dapat memasukan NGT } \\
\text { Terdengarnya suara bising } \\
\text { usus pada auskultasi dada }\end{array}$ \\
\hline
\end{tabular}

Pada literatur dijelaskan berbagai macam modalitas untuk menegakkan diagnosis ruptur diafragma yang berupa studi kohort dan case series. Al-Refaie dkk. melaporkan diagnosis ruptur diafragma akibat trauma tumpul ditegakkan pada 12 jam pertama sejak kedatangan di Instalasi Gawat Darurat sebesar $56,5 \%$ yang terdiagnosis hanya melalui foto polos toraks, 26,1\% terdiagnosis dalam 24 jam pertama dengan menggunakan CT Scan dan $17,4 \%$ lainnya membutuhkan diagnosis yang lebih lama. ${ }^{6}$

Pada minoritas pasien yang memperlihatkan tanda dan gejala ruptur terherniasi akibat perbedaan tekanan antara diafragma termasuk di dalamnya distres rongga abdomen dengan rongga intrapleura. pernapasan, abnormalitas jantung, deviasi Pemasangan chest tube tidak akan trakea dan suara usus pada rongga dada. memperbaiki distres pernapasan, namun dapat Walaupun gejala dan tanda dapat ditemukan, meningkatkan kerusakan iatrogenik terhadap biasanya gejala dan tanda kelainan organ lain organ abdomen yang masuk ke dalam rongga akibat multipel trauma lebih dominan tampak. ${ }^{3}$

Distres pernapasan merupakan keadaan mengancam nyawa dari gejala ruptur diafragma akibat herniasi organ intraabdominal ke dalam rongga toraks sehingga paru menjadi kolaps dan pergeseran mediastinum ke arah kontralateral. ${ }^{2}$ Pada keadaan hemopneumotoraks, chest tube dengan WSD harus dipasang. Pada beberapa kasus rongga yang tercipta setelah darah atau udara intrapleura dialirkan melalui chest tube akan digantikan dengan organ abdomen yang organ abdomen yang masuk ke dalam rongga 
toraks. Jika pasien tidak dapat mengompensasi oksigen dengan mask, intubasi dan ventilasi mekanik merupakan tatalaksana yang tepat untuk ruptur diafragma, Intubasi dan ventilasi mekanik dengan tekanan positif bahkan akan dapat mengurangi hernia visera, sehingga dapat memperbaiki status hemodinamik, namun terlambat mendiagnosis. ${ }^{2,7}$ Pada kasus 1, pasien dapat membaik dengan pemberian oksigen melalui mask dan dari hasil analisa gas darah, pasien belum ada indikasi pemasangan ventilasi mekanik.

Berlawanan dengan kasus 2, pasien datang dengan keluhan utama nyeri pada perut bagian atas. Gejala gangguan pernapasan tidak terlihat pada pasien karena berlangsung secara kronik. Foto polos toraks hanya memperlihatkan elevasi diafragma kiri. Gejala yang tidak spesifik dan gambaran foto polos toraks ini disimpulkan sebagai eventratio. Kondisi ini sering sukar dibedakan dengan ruptur diafragma pada pasien dengan trauma. Biasanya pertama kali ditemukan pada periode neonatal dengan distres pernapasan, namun jika pertama kali ditemukan pada saat dewasa, hal ini menjadi dilema dalam mendiagnosis dengan ruptur diafragma akibat trauma. Kasus eventratio yang ditemukan pada saat dewasa tanpa gejala sebelumnya sangat jarang terjadi, sehingga dugaan yang harus pertama kali dipikirkan oleh dokter dengan gejala serupa pasien kasus 2 adalah adanya ruptur diafragma akibat trauma sehingga perlu digali dalam anamnesis adanya riwayat trauma sebelumnya baik yang baru saja terjadi sampai puluhan tahun sebelum gejala timbul. Diagnosis ruptur diafragma pada pasien kasus 2 ditegakkan intraoperatif.

Eventratio diafragma merupakan kondisi yang jarang dimana otot diafragma terelevasi secara permanen, namun intak dan tetap melekat pada batas iga. Indikasi operasi pada eventratio yang ditemukan pada pasien dewasa adalah elevasi diafragma dengan adanya gejala yang memanjang. Gejala yang dapat timbul pada pasien dengan eventratio adalah dispnoe, ortopnoe, nyeri pada dinding dada, batuk serta dispepsia dan meteorismus. Pada sisi lain, diagnosis secepatnya dan memperbaiki segera pada ruptur diafragma penting dilakukan untuk menghindari terjadinya herniasi, inkarserata dan srangulasi dari visera abdominal. Modalitas pencitraan multipel dilakukan preoperatif. Jika pada foto polos toraks tidak dapat dibedakan, maka sebaiknya dilakukan CT Scan. ${ }^{8}$

Pemeriksaan foto polos toraks secara rutin pada pasien multipel trauma merupakan hal terbaik yang harus dilakukan. Foto polos toraks merupakan alat untuk mengevaluasi pasien dengan ruptur diafragma. Penemuan kelainan pada foto polos toraks merupakan sugestif namun tidak spesifik untuk ruptur diafragma termasuk hemidiafragma yang mengalami elevasi. Tanda spesifik yang ditemukan pada foto polos toraks adalah adanya visera abdominal atau nasogastric tube pada dada, "collar sign" (herniasi dari viscera abdominal) dan elevasi diafragma. Tanda lainnya yang sensitif namun tidak spesifik adalah kaburnya batas diafragma, pergeseran mediastinum ke arah kontralateral, atelektasis pada lobus bawah paru serta efusi pleura. ${ }^{2,3,6,7}$ Namun, kondisi apapun yang mengaburkan rongga pleura seperti hemotoraks dan kontusio paru dapat menyerupai gambaran foto polos toraks pada ruptur diafragma. Ruptur diafragma tanpa terjadinya herniasi visera tidak mempunyai temuan spesifik pada foto polos toraks. ${ }^{3}$ Akurasi diagnosis pada foto polos toraks empat kali lebih besar pada sisi kiri dibandingkan sisi kanan. ${ }^{7}$ Pada literatur foto polos toraks mempunyai sensitivitas $27-73 \%$ pasien dan nilai diagnostik akan naik sebesar 8-25\% dengan foto polos toraks serial dalam 24 jam pertama. Pada studi Al-Rifaie sensitivitas foto polos toraks sebesar 30-62\% 
jika tidak terdapat hernia, sensitivitas ini naik jika adanya hernia. ${ }^{6}$ Oleh karena itu foto polos toraks merupakan alat pencitraan diagnostik lini pertama. ${ }^{2}$ Foto roentgen yang atipikal pada trauma torakoabdominal akut terutama sisi kiri sebaiknya dilakukan pencitraan selanjutnya dan disarankan CT scan jika pasien dalam keadaan stabil. ${ }^{7}$

Computed Tomography (CT) merupakan alat diagnostik selanjutnya yang dilakukan pada pasien dengan trauma tumpul dengan hemodinamik stabil. Selain itu dengan CT, dapat juga dinilai kelainan pada organ-organ lainnya intratorakal dan intraabdomen. CT konvensional mempunyai sensitivitas 14 $82 \%$ dan spesifisitas $87 \%$. Helical CT menaikan sensitivitas menjadi 71-100\% dan spesifisitas menjadi 75-100\%. Multidetektor CT (MDCT) memperlihatkan potongan yang lebih tipis sehingga lebih detail mencitrakan kelainan dengan waktu yang lebih singkat dan fleksibilitas yang besar pada rekonstruksi pencitraan. Keakuratan diagnosis MDCT untuk mendeteksi ruptur diafragma masih diteliti. Tanda ruptur diafragma pada CT termasuk visualisasi direk dari ruptur diafragma, nonvisualisasi diafragma segmental, herniasi visera abdomen ke dalam intratorakal, "the hump sign" dan "the band sign" (dua tanda pada potongan sagital dan koronal yang memperlihatkan herniasi hati), "the collar sign" (konstriksi usus dan mesenterium yang terherniasi melalui defek diafragma), "dangling diaphragm sign" (ujung diafragma tergulung ke arah dalam menjauhi posisi normal, sejajar dengan dinding abdomen), "dependent viscera sign" (tidak adanya struktur penggantung posterior oleh diafragma menyebabkan visera terlihat menggantung ke arah iga posterior), penebalan diafragma serta ekstravasasi kontras aktif peridiafragmatika., 2,7,9

Magnetic Resonance Imaging (MRI) memperlihatkan pencitraan seluruh diafragma dan memperlihatkan perbedaan yang sangat jelas antara diafragma dan struktur di sekitarnya. Hambatan pada pasien dengan multipel trauma disebabkan oleh ruang magnetik yang tidak sesuai dengan beberapa alat monitoring serta prosedur yang dilakukan cukup lama. Biasanya, MRI dilakukan pada pasien dengan hemodinamik yang stabil. ${ }^{2}$

Ultrasonografi juga dapat menjadi alat diagnostik pada pasien dengan ruptur diafragma, terutama pada Focused Abdominal Sonography for Trauma (FAST) dapat diperluas ke arah rongga toraks untuk melihat hemotoraks dan menilai pergerakan diafragma (menggunakan m-mode jika memungkinkan). Pemeriksaan ini membutuhkan waktu, namun dapat melihat pergerakan diafragma, herniasi visera, atau flap dari ruptur diafragma. ${ }^{2}$ Mihos dkk. menjelaskan akurasi diagnostik ruptur diafragma di Instalasi Gawat Darurat menggunakan ultrasonografi sebesar $26 \%$. $^{7}$

Penggunaan kontras pada pencitraan lainnya seperti fluoroskopi, liver-spleen scintigraphy pneumoperitonium jarang digunakan, namun berguna pada pasien stabil saat CT dan MRI tidak digunakan. ${ }^{2}$

Diagnostic Peritoneal Lavage (DPL) dapat mendiagnosis secara tidak langsung pada ruptur diafragma dengan perdarahan intraabdominal pada 87-94\%. Namun hasil yang negatif palsu harus dipikirkan. Enambelas persen pasien dengan ruptur diafragma kiri mempunyai hasil yang negatif pada pemeriksaan DPL yang didapat dari sebuah studi case series 59 pasien. $^{2}$

Tindakan operasi pada ruptur diafragma harus dilakukan secepat mungkin, sehingga tidak terjadi perburukan dari gangguan pernafasan dan sirkulasi akibat efek volume, cairan pada pleura, pneumoperitoneum, jika terdapat herniasi organ intraabdomen, maka tidak terjadi perburukan obstruksi, inkarserata atau strangulasi. Tindakan operasi ini dapat merupakan tindakan diagnostik maupun 
terapeutik. Pilihan pendekatan operasi untuk menatalaksana termasuk laparoskopi, torakoskopi, laparotomi dan torakotomi. Walaupun masing-masing hemidiafragma lebih besar terekspos melalui rongga toraks, setiap pendekatan terbaik harus dilakukan untuk masing-masing pasien. Terdapat kelainan pada organ abdomen lebih baik dilakukan pendekatan melalui abdomen. Pada periode akut paska trauma, repair diafragma melalui pendekatan dimana organ lain yang juga harus diperbaiki berada. Symbas dkk. menatalaksana kasus trauma pada diafragma melalui insisi laparotomi. Jika eksplorasi abdominal tidak diindikasikan, torakotomi dapat dilakukan. Ruptur hemidiafragma kiri lebih sering dilakukan operasi transabdominal karena seringnya keterkaitan dengan kelainan organ abdomen lainnya. ${ }^{3,5,6,10}$

Pemilihan tindakan operasi yang dilakukan diawali dengan menstabilkan kondisi pasien dan mendiagnosis kelainan pada organ lainnya. Kemudian pasien akan terbagi menjadi dua kategori:

- ruptur diafragma terisolasi (kurang dari $10 \%$ dari semua pasien trauma dengan ruptur diafragma),

- hernia diafragma berkaitan dengan multipel trauma.

Tindakan terbaik pada pasien dengan ruptur diafragma terisolasi adalah dengan torakoskopi dan laparoskopi. Teknik ini dapat digunakan untuk mendiagnosis dan memperbaiki diafragma secara aman untuk mengurangi ukuran defek diafragma. Defek yang besar termasuk herniasi organ mayor dapat diperbaiki melalui torakotomi atau laparotomi. $^{3} \quad$ Ruptur diafragma akut direkomendasikan pendekatan melalui abdomen karena sebesar $89 \%$ pasien dengan trauma ini mempunyai kelainan organ abdomen atau pelvis. Sedangkan pasien dengan ruptur diafragma laten (lebih dari hari ketujuh) mempunyai perlengketan (adhesi) antara organ abdomen yang terherniasi dengan organ intratoraks sehingga pendekatan terbaik adalah melalui torakotomi. ${ }^{2,6,11}$ Niville dkk. menambahkan pilihan pendekatan yang direkomendasikan oleh mereka adalah melalu abdomen, karena melalui insisi ini dapat dengan mudah diperluas ke rongga toraks jika diperlukan. McCune dkk. merekomendasikan pendekatan melalui toraks untuk memperbaiki ruptur diafragma kanan karena diagnosis lebih sering terlambat ditegakkan. ${ }^{3}$ Laparotomi lebih tepat pada pasien tidak stabil dengan kelainan lain pada intra-abdominal. Selanjutnya pemeriksaan kedua hemidiafragma wajib dilakukan. Torakotomi lebih tepat pada pasien yang lebih stabil tanpa adanya kelainan lain organ intra-abdominal dan tanpa kelainan pada hemidiafragma kontralateral. $^{12}$

Pendekatan yang dilakukan pada pasien kasus 1 adalah melalui laparotomi mengingat pasien ditemukan pada fase akut dan defek diafragma yang cukup besar yaitu $8 \mathrm{~cm}$. Insisi melalui abdomen dipilih karena operator dapat memeriksa kelainan organ intra-abdominal lainnya yang sering terjadi pada pasien ruptur diafragma dan dapat memeriksa hemidiafragma kontralateral untuk melihat adanya ruptur diafragma terisolasi pada sisi kontralateral, selain itu juga dapat dengan mudah diperluas ke rongga toraks jika diperlukan. Sedangkan pendekatan pada kasus 2 adalah torakotomi karena kasus 2 adalah kasus pada fase laten dimana sering ditemukan perlengketan antara organ abdomen dengan organ toraks. Pasien kasus 2 juga tidak ditemukan adanya tanda-tanda peritonitis akibat adanya perforasi gaster. Namun, jika ditemukan adanya kelainan pada organ abdomen, maka dapat dilakukan torakolaparotomi.

\begin{tabular}{crr} 
Laparoskopi & atau & \multicolumn{2}{c}{ Video-Assisted } \\
Thoracoscopy & Surgery & (VATS) dapat
\end{tabular} digunakan jika pasien dengan hemodinamik 
yang stabil. VATS mempunyai nilai akurasi yang lebih besar (sensitivitas dan spesifisitas $100 \%$ ) dan membantu menghindari tension pneumotoraks. VATS digunakan pada pasien dengan pasien terpasang WSD dengan adanya bukti tidak adanya kerusakan pada organ intraabdominal. VATS menghindari insuflasi gas dan memperbolehkan untuk menemukan kelainan lain pada organ intratorakal dan melakukan terapi sekaligus. Kekurangannya adalah berkaitan dengan penggunaan doublelumen endobroncheal tube dan hemidiafragma kontralateral tidak dapat dinilai. VATS baik dilakukan pada pasien stabil dengan eksklusi kelainan organ intra-abdominal dan hemidiafragma kontralateral. Dengan menggunakan laparoskopi, maka penilaian terhadap organ intra-abdominal dan hemidiafragma kontralateral dapat dilakukan. ${ }^{2}$

Tindakan operasi tidak dapat ditentukan sama terhadap semua kasus ruptur diafragma. Setiap kasus mempunyai tatalaksana yang berbeda-beda antara yang satu dengan yang lain. Hal ini tergantung dari akut atau laten suatu kasus, stabil atau tidak stabil kondisi pasien, kelainan organ lainnya, serta pengalaman operator. Sampai saat ini belum ada hasil metaanalisis, rekomendasi atau bahkan uji klinik dengan kontrol yang terandomisasi mengenai pemilihan pendekatan terbaik pada pasien ruptur diafragma.

Jenis penjahitan diafragma masih kontroversial. Mayoritas memilih single layer of interrupted non-absorbable suture, walaupun sampai saat ini belum ada penelitian prospektif atau retrospektif yang meneliti teknik penjahitan diafragma. ${ }^{3}$ Penggunaan benang non-absorbable sangat direkomendasikan, walaupun penggunaan dengan benang absorbable pernah dilaporkan. Baik teknik interrupted maupun continuous keduanya efektif digunakan.Beberapa penulis melakukan penjahitan diafragma dilakukan dengan figure-of-eight benang nonabsorbable berkaliber besar., ${ }^{2,6}$ Materi prostetik (mesh) terkadang dibutuhkan jika dipikirkan defek terlalu besar atau pada pasien dengan terlambat diagnosis dan penjahitan saja akan menghasilkan tension. ${ }^{2,5}$

William dkk. melaporkan bahwa angka mortalitas ruptur diafragma sebesar 23\% sedangkan Shah dkk. melaporkan bahwa angka mortalitas sebesar 17\% pada diagnosis akut. Mayoritas morbiditas pasien yang dilakukan operasi berkaitan dengan komplikasi paru-paru., ${ }^{3,11}$ Al-Rifaie dkk. menemukan morbiditas paska operasi sebesar 11-62,9\% dan masalah paru merupakan komplikasi tersering berupa atelektasis, ARDS, efusi pleura dan empyema. ${ }^{6}$ Rowlands dkk. menemukan bahwa $75 \%$ pasien yang datang dengan diagnosis ruptur diafragma mempunyai kelainan pada organ lainnya. Sarna dkk. dan Mihos dkk. melaporkan pada dua laporan yang berbeda bahwa 84-95\% pasien dengan ruptur diafragma mempunyai kelainan pada organ abdomen, yang tersering adalah hati, limpa dan usus. ${ }^{3}$ Al-Rifaie dkk. melaporkan, kelainan organ lainnya yang sering yang terjadi pada ruptur diafragma akibat trauma tumpul adalah trauma limpa dan hepar, fraktur iga, dan trauma pada paru. ${ }^{6}$ Drews dkk. memberi kesimpulan bahwa: ${ }^{13}$

1. Trauma apapun jika meliputi area sela iga keempat sampai umbilikus harus dipikirkan mengenai diafragma.

2. Evaluasi dengan menggunakan foto polos dada sangat penting. Jika pada foto polos dada ditemukan kelainan pada diafragma dan operasi tidak langsung dikerjakan karena alasan tertentu, maka dilakukan pemeriksaan menggunakan kontras untuk mendapatkan jawaban bahwa diafragma intak atau tidak.

3. Walaupun tidak ditemukan indikasi operasi lainnya, ruptur diafragma akut 
harus segera dilakukan dengan interrupted nonabsorbable sutures.

4. Eksplorasi abdomen diperintahkan pada trauma akut, serta pemeriksaan fisik yang hati-hati pada seluruh diaragma harus menjadi bagian dari eksplorasi abdomen karena trauma.

\section{SIMPULAN}

Ruptur diafragma perlu dicurigai pada semua pasien dengan trauma terutama jika mengalami trauma tumpul daerah abdomen dan pinggang terutama bagian lateral. Adanya dianosis banding ruptur diafragma pada pasien dewasa dengan gejala abdomen bagian atas ataupun foto polos toraks yang menggambarkan eventratio atau elevasi diafragma sehingga perlu ditanyakan adanya riwayat trauma baik yang terjadi beberapa hari lalu, maupun bertahun-tahun yang lalu. Pemeriksaan fisik paru yang teliti ditambah dengan foto polos toraks harus dilakukan pada pasien yang dicurigai mengalami ruptur diafragma. Jika tidak ditemukan kelainan, maka dapat dilakukan foto polos toraks serial dan CT scan dengan kualitas tinggi pada pasien stabil untuk mendiagnosis ruptur diafragma dan kelainan lainnya pada organ toraks dan abdomen. Tindakan operasi merupakan tindakan yang wajib dilakukan untuk memperbaiki diafragma. Pendekatan yang dipakai baik laparotomi, torakotomi, laparoskopi dan VATS tergantung dari akut atau laten suatu kasus, stabil atau tidak stabil kondisi pasien, kelainan organ lainnya, serta pengalaman operator.

\section{UCAPAN TERIMA KASIH}

Tidak ada.

\section{PERNYATAAN}

Penulis menyatakan bahwa laporan ini tidak terdapat konflik kepentingan.

\section{DAFTAR PUSTAKA}

1. Rachmad KB. Ruptur Diafragma. In: Rachmad KB. Penanganan Trauma Toraks. Jakarta: Pendidikan Berkelanjutan untuk Ahli Bedah. Subbagian Bedah Toraks, Bagian Ilmu Bedah FKUI / RSUPNCM; 2002. p.73-9.

2. Matsevych OY. Blunt Diaphragmatic Rupture: Four Year's Experience. Hernia. 2008;12:73-8.

3. Force SD. Management of Acute Diaphragmatic Rupture: Thoracotomy Versus Laparotomy. In: Ferguson MK, editor. Difficult Decision in Thoracic Surgery An Evidence Based Approach. London: Springer; 2007. p.379-84.

4. Simpson J, Lobo DN, Rowlands BJ. Traumatic Diaphragmatic Rupture: Associated Injuries and Outcome. Ann $R$ Coll Surg Engl. 2000; 82:97-100.

5. Guitron J, Howington J, LoCicero J. Diaphragmatic Injuries. In: Shields TW, Locicero J, Reed CE, dkk, editors. General Thoracic Surgery. 7th Ed. Vol. 1. New York: Lippincott Williams and Wilkins; 2009. p.937-44.

6. Al-Refaie RE, Awad E, Mokbel EM. Blunt Traumatic Diaphragmatic Rupture: A Retrospective Observational Study of 46 Patients. Interactive Cardiovascular and Thoracic Surgery. 2009;9:45-9.

7. Morgan BS, Watcyn-Jones T, Garner JP. Traumatic Diaphragmatic Injury. JR Army Med Corps. 2010;156:139-49.

8. Mantoo SK, Mak K. Congenital Diaphragmatic Eventration In An Adult: A Diagnostic Dilemma. Singapore Med J. 2007;48:e136-7.

9. Desser TS, Edwards B, Hunt S, dkk. The Dangling Diaphragm Sign: Sensitivity and Comparison with Existng CT signs of Blunt Traumatic Diaphragmatic Rupture. Emerg Radiol. 2010;17:37-44. 
10. Simpson J, Lobo DN, Shah AB, dkk. 12. Tan KK, Yan ZY, Vijayan A, dkk. Traumatic Diaphragmatic Rupture: Management of Diaphragmatic Rupture Associated Injuries and Outcome. Ann $R$ from Blunt Trauma. Singapore Med J. Coll Surg Engl : 2000;82:97-100. 2009;50:1150-3.

11. Shah R, Sabanathan S, Mearns AJ, dkk. 13. Drews JA, Mercer EC, Benfield JR. Acute Traumatic Rupture od Diaphragm. Ann diaphragmatic injuries. Ann Thorac Surg. Thorac Surg. 1995;60:1444-9. 1973;16:67-88. 